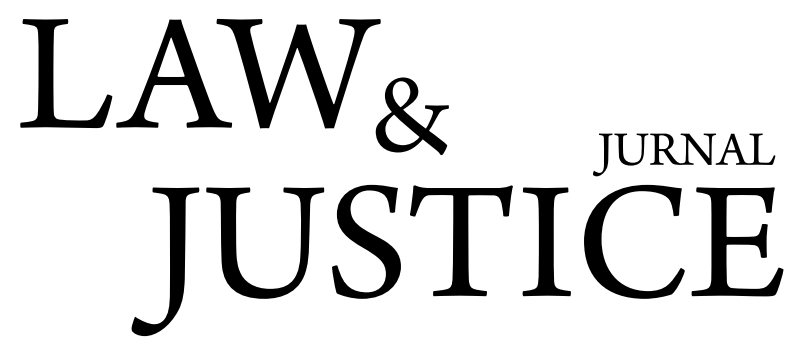

\title{
LANGKAH-LANGKAH MENGATASI DEINDUSTRIALISASI DALAM UNDANG-UNDANG NOMOR 3 TAHUN 2014 TENTANG PERINDUSTRIAN
}

\author{
Alexander Dwi Agung Situmorang \\ Universitas Sebelas Maret Surakarta \\ Jalan Ir Sutami No 36-A Kentingan Surakarta. Kode Pos, 57126 \\ Itok Dwi Kurniawan \\ Universitas Sebelas Maret Surakarta \\ Jalan Ir Sutami No 36-A Kentingan Surakarta. Kode Pos, 57126 \\ Email: itokdwikurniawan@gmail.com
}

\begin{abstract}
Abstrak
Penelitian ini bertujuan meneliti langkah-langkah pemerintah untuk mengatasi deindustrialisasi menurut Undang-Undang Nomor 3 Tahun 2014 tentang Perindustrian. Penyebab deindustrialisasi adalah meningkatnya tren ekspor bahan mentah jika dibandingkan produk olahan, banyaknya barang impor yang masuk ke Indonesia, dan lambatnya pembangunan infrastruktur di Indonesia. Untuk mengatasi masalah deindustrialisasi, Undang-Undang Nomor 3 Tahun 2014 tentang Perindustrian telah mengatur beberapa langkah penting, di antaranya pembangunan sumber daya Industri, tindakan penyelamatan dan pengamanan produk industri, mempercepat perizinan dan pendirian industri, mempermudah penanaman modal industri, dan pembangunan sarana dan prasarana untuk peningkatan daya saing industri. Langkah-langkah tersebut masih sangat sulit dilaksanakan karena tidak sinkronnya peraturan pemerintah, baik di tingkat pusat dan daerah; buruknya iklim investasi dan daya saing, dan buruknya infrastruktur di Indonesia.
\end{abstract}

Kata kunci: Deindustrialisasi, Perindustrian, Iklim Investasi, Infrastruktur.

\section{Pendahuluan}

Pada tanggal 7 Oktober 2003 di Bali, para pemimpin negara ASEAN menandatangani kesepakatan untuk membentuk ASEAN Economic Community (AEC) yang akan mulai berlaku mulai tahun 2020. Cetak biru AEC menyatakan bahwa AEC akan meningkatkan integrasi ekonomi dan mentransformasi ASEAN menjadi entitas ekonomi dengan free movement of goods, services and skilled labour, and free flow of capital. Namun, kesepakatan di Filipina pada tahun 2007 bahkan mempercepat waktu penerapan menjadi 2015.

Free movement of goods and services berarti semua tarif barang impor akan turun menjadi nol persen (ada perpanjangan sampai 2018 untuk beberapa produk katagori sensitif). Butir ini memaksa 
hasil produksi Indonesia untuk berkompetisi langsung dengan negara ASEAN. Jika tidak mampu, berarti 250 juta warga negara Indonesia hanya menjadi konsumen dan pembeli.

Bidang kebebasan dalam sektor finansial, Indonesia bahkan tidak membutuhkan AEC ketika sejak 1999 entitas usaha asing dapat memiliki 99\% saham perbankan di Indonesia dan hampir semua bank swasta besar di Indonesia sahamnya tidak lagi mayoritas di tangan warga negara Indonesia.

Adapun kesepakatan free movement of skilled labor, artinya professional (manajer, akuntan, marketing, ahli IT dll) dari negara ASEAN bisa bekerja di Indonesia, sedangkan 94,4 \% tenaga kerja Indonesia yang berpendidikan SMA ke bawah tentu tidak bisa dengan mudah bekerja di negara ASEAN.

Terbukanya pasar ASEAN sebenarnya bisa menjadi kesempatan bagi produsen Indonesia untuk meningkatkan ekspor ke sembilan negara anggota lainnya. Masalahnya, kinerja sektor manufaktur Indonesia tidak lagi seperti pada periode 1990-1996 yang pertumbuhan tahunannya mencapai $12 \%$ dan merupakan sepertiga pertumbuhan ekonomi Indonesia. Dari total ekspor Indonesia tahun 2011, lebih dari dua pertiga $(68,3 \%)$ adalah komoditas atau bahan baku dengan hampir sepertiganya $(31,3 \%)$ adalah migas. Hanya 31, 4 \% ekspor Indonesia yang merupakan produk manufaktur (Martawardaya, 2013). Hal ini berbeda dengan Saudi, Kuwait dan Bahrain dengan cadangan minyak raksasa yang masih bertahan lama, migas di Indonesia diperkirakan habis dalam 30-40 tahun lagi.

Melihat kenyataan di atas, salah satunya adalah menurunnya kinerja sektor manufaktur Indonesia merupakan pertanda de-industrialisasi. Negara Indonesua tidak seperti Malaysia, Thailand, dan Korsel yang mampu bangkit kembali dengan cepat pasca krisis moneter akhir 90-an, pertumbuhan sektor manufaktur Indonesia lebih lambat dari pertumbuhan ekonomi nasional sehingga proporsi manufaktur terhadap total ekonomi menurun sampai $25,7 \%$ pada tahun 2011. Angka ini jauh di bawah Thailand yang mencapai $43 \%$ dan Korea Selatan yang $39 \%$ (Pratiwi Kartika, 2009).

Manufaktur bukan lagi motor pertumbuhan ekonomi Indonesia, padahal sektor ini di berbagai negara adalah andalan untuk menyerap migrasi pekerja dari sektor pertanian, baik yang temporer setelah menanam pangan dan menunggu panen maupun yang permanen tidak mau lagi menjadi petani. Sektor manufaktur juga secara bertahap meningkatkan pengetahuan teknologi pekerja untuk bertahap memasuki industri high tech seperti yang dilakukan Taiwan, Korsel dan Jepang.

Pada periode 2004-2011 ekonomi Indonesia mengalami pertumbuhan 54,1 \%. Sekarang, satusatunya sub-sektor manufaktur yang tumbuh lebih tinggi adalah peralatan, mesin, dan transportasi (67\%) yang sebagian besar berupa mobil dan motor tidak satu pun bermerk nasional. Meskipun cukup banyak komponen dibuat dan perakitannya di Indonesia, namun komponen termahal (mesin) masih diimpor dan sebagian profit dibawa kembali ke negara asal. Penggunaan mobil dan motor juga menimbulkan kemacetan dan polusi yang mengurangi produktivitas pekerja Indonesia.

Penjelasan di atas mengaitkan terjadinya deindustrialisasi karena menurunnya produktivitas sektor manufaktur, sektor yang menghasilkan barang. Salah satu bentuknya adalah proporsi pekerja di bidang manufaktur yang menurun jika dibandingkan total seluruh pekerja.

Di Indonesia, terjadinya gejala deindustrialisasi juga sudah dinyatakan oleh para pengusaha. Ketua Umum Kamar Dagang dan Industri (Kadin) Indonesia Rosan Roeslani menyatakan Indonesia mengalami penurunan pertumbuhan industri atau deindustrialisasi dalam 10 tahun terakhir. Angka kontribusi industri terhadap Produk Domestik Bruto (PDB) saat ini tidak setinggi pada era 1990-an hingga awal 2000 (Dimas Jarot Bayu, Kadin: Selama 10 Tahun Indonesia Alami Deindustrialisasi, diakses dari katadata.com/2017/01/kadin-selama-10-tahun-indonesia-alami-deindustrialisasi, pada tanggal 3 April 2017, pukul 17. 55 WIB.)

Berdasarkan latar belakang di atas, penulis ingin meneliti langkah-langkah mengatasi deindustrialiasi yang ada dalam Undang-Undang Nomor 3 Tahun 2014 tentang Perindustrian. Undangundang perindustrian yang baru ini menggantikan Undang-Undang Nomor 5 Tahun 1984 tentang Perindustrian yang dinilai sudah tidak sesuai dengan perubahan paradigma pembangunan industri. Salah satu tujuan pembaruan undang-undang perindustrian ini adalah bahwa pembangunan nasional di bidang ekonomi dilaksanakan dalam rangka menciptakan struktur ekonomi yang kukuh melalui pembangunan industri yang maju sebagai motor penggerak ekonomi yang didukung oleh kekuatan dan kemampuan sumber daya yang tangguh. 


\section{Metode Penelitian}

Penelitian ini adalah penelitian hukum normatif atau penulisan doctrinal. Penulisan yang dilakukan oleh penulis bersifat eksplanatoris. Dalam penelitian hukum ini bertujuan meneliti langkah-langkah pemerintah untuk mengatasi deindustrialisasi menurut Undang-Undang Nomor 3 Tahun 2014 tentang Perindustrian. Pendekatan yang digunakan adalah Pendekatan Undang-Undang (Statute Approach) dan Pendekatan Perbandingan (Comparative Approach), bahan hukum terdiri dari bahan hukum primer, sekunder dan tersier. Dalam penelitian ini menggunakan teknik pengumpulan sumber penelitian berupa teknik riset kepustakaan (library research).

\section{Pembahasan}

\section{Definisi Deindustrialisasi}

Secara umum, deindustrialisasi dapat diartikan sebagai penurunan output sektor manufaktur dalam pendapatan nasional dan penurunan pangsa (share) pekerja sektor manufaktur terhadap total pekerja. Di bawah ini akan dijelaskan beberapa pengertian industrialisasi dari para ahli.

a. Blackaby (1979) diacu dalam Jalilian dan Weiss (2000) menyatakan bahwa deindustrialisasi adalah penurunan nilai tambah riil sektor manufaktur atau penurunan kontribusi sektor manufaktur dalam pendapatan nasional (Meinara, 2010).

b. Rowthorn dan Wells (1987) diacu dalam IMF (1997) menyatakan bahwa deindustrialisasi adalah penurunan proporsi jumlah pekerja sektor manufaktur terhadap total pekerja (Meinara, 2010).

Teori yang menjelaskan deindustrialisasi sudah berkembang sejak lama. Rowthorn dan Wells membedakan deindustrialisasi menjadi dua, yaitu deindustrialisasi positif dan deindustrialisasi negatif. Deindustrialisasi positif terjadi karena pembangunan ekonomi sudah mencapai tahap kedewasaan. Sedangkan deindustrialisasi negatif merupakan fenomena patologis (pathological phenomenon) yaitu terjadi ketidakseimbangan struktural dalam perekonomian yang mencegah suatu bangsa mencapai pertumbuhan yang full employment. Keadaan ini terjadi karena memburuknya kinerja sektor manufaktur dan melambatnya pertumbuhan output dan produktivitas sektor manufaktur yang mengakibatkan menurunnya daya saing sehingga perekonomian semakin memburuk. Pengangguran dari sektor manufaktur yang dihasilkan dari adanya deindustrialisasi negatif tidak dapat terserap di sektor jasa akibat situasi perekonomian yang melambat. Dengan demikian, deindustrialisasi positif dikaitkan dengan meningkatnya pendapatan riil dan lapangan kerja penuh (full employment), sementara deindustrialisasi negatif dikaitkan dengan stagnasi pendapatan riil dan meningkatnya pengangguran.

Rowthorn dan Wells (1987) berpendapat bahwa adanya perdagangan dalam perekonomian internasional terkait dengan deindustrialisasi. Perdagangan mempengaruhi peran pekerja manufaktur baik secara makro maupun mikro ekonomi melalui pengaruhnya pada spesialisasi. Pertama, dalam economic maturity deindustrialisasi terkait dengan kinerja perdagangan yang kuat atau lemah. Pada saat neraca perdagangan manufaktur positif dan besar, kekuatan sektor manufaktur memberikan kontribusi pada pertumbuhan ekonomi yang berkelanjutan. Keadaan ini tercapai pada saat sektor manufaktur mulai melimpahkan tenaga kerjanya yang dapat diserap oleh sektor jasa (melalui deindustrialisasi positif). Sebaliknya, ketika perdagangan manufaktur memburuk dan investasi di bidang manufaktur menurun, sektor manufaktur mulai melimpahkan tenaga kerjanya dan tidak dapat terserap oleh sektor jasa sehingga perekonomian stagnan atau semakin memburuk (melalui deindustrialisasi negatif) (Meinara, 2010).

\section{Penyebab Deindustrialisasi di Indonesia}

Deindustrialisasi sering diasosiasikan dengan menurunnya daya saing industri sebuah bangsa. Rendahnya kondisi daya saing Indonesia, disebabkan oleh buruknya kinerja perekonomian nasional dalam 4 (empat) hal pokok, yaitu: (a) buruknya kinerja perekonomian nasional yang tercermin dalam kinerjanya di perdagangan internasional, investasi, ketenagakerjaan, dan stabilitas harga, (b) buruknya 
efisiensi kelembagaan pemerintahan dalam mengembangkan kebijakan pengelolaan keuangan negara dan kebijakan fiskal, pengembangan berbagai peraturan dan perundangan untuk iklim usaha kondusif, lemahnya koordinasi akibat kerangka institusi publik yang masih banyak tumpang tindih, dan kompleksitas struktur sosialnya, (c) lemahnya efisiensi usaha dalam mendorong peningkatan produksi dan inovasi secara bertanggung jawab yang tercermin dari tingkat produktivitasnya yang rendah, pasar tenaga kerja yang belum optimal, akses ke sumber daya keuangan yang masih rendah, serta praktik dan nilai manajerial yang relatif belum profesional, dan (d) keterbatasan di dalam infrastruktur, baik infrastruktur fisik, teknologi, maupun infrastruktur dasar yang berkaitan dengan kebutuhan masyarakat akan pendidikan dan kesehatan (World Bank, 2014).

Meskipun permasalahan penurunan daya saing ini berawal sebelum krisis tahun 1997, perkembangan industri sangat memburuk setelah krisis tahun 1997. Banyak pengamat mengindikasikan terjadinya "deindustrialisasi". Gejala ini ditunjukkan dengan mengamati perkembangan tingkat realisasi kapasitas produksi (utilisasi kapasitas), jumlah perusahaan, dan indeks produksi. Penelaahan terhadap ketiga hal tersebut menyimpulkan beberapa penyebab masalah deindustrialisasi di Indonesia, yaitu sebagai berikut (Kementerian Perindustrian, 2013).

a. KKN dan layanan umum yang buruk mengakibatkan tingginya biaya overhead. Menurut kajian Komite Pemantau Pelaksanaan Otonomi Daerah (KPPOD), pengeluaran untuk berbagai pungutan dan untuk biaya buruknya layanan umum menambah biaya overhead sekitar 8,7 persen - 11,2 persen.

b. Cost of money yang relatif tinggi, tecermin dari suku bunga yang saat ini sangat tinggi. Pengusaha dalam negeri yang mengandalkan perbankan dalam negeri akan kalah bersaing dengan perusahaan yang modal kerjanya dari luar negeri dengan bunga berkisar 4-6 persen.

c. Administrasi perpajakan yang belum optimal. Pengusaha menganggap administrasi perpajakan terutama dalam kaitannya dengan restitusi produk-produk industri ekspor sangat tidak efisien. Hal tersebut mengakibatkan daya saing produk ekspor menjadi berkurang karena ketidakefisiensian tersebut dibebankan ke harga jualnya. Selain itu, hal tersebut juga tidak kondusif untuk integrasi antar industri terkait untuk pengadaan bahan antaranya. Pada umumnya mereka memilih untuk impor bahan baku atau produk antara karena sejak awal tidak terkena PPN.

d. Kandungan impor sangat tinggi. Nilai impor bahan baku, bahan antara (intermediate), dan komponen untuk seluruh industri meningkat dari 28 persen pada tahun 2003 menjadi 30 persen pada tahun 2012. Khusus untuk industri tekstil, kimia, dan logam dasar nilai tersebut mencapai 30-40 persen, sedangkan untuk industri mesin, elektronik dan barang-barang logam mencapai lebih dari 60 persen. Tingginya kandungan impor ini mengakibatkan rentannya biaya produksi terhadap fluktuasi nilai tukar rupiah dan kecilnya nilai tambah yang mengalir pada perekonomian domestik.

e. Lemahnya penguasaan dan penerapan teknologi. Nilai tambah industri nasional relatif rendah, hal ini menunjukkan bahwa karakteristik industri manufaktur masih tipe "tukang jahit," meskipun dalam komposisi ekspor mulai terjadi peningkatan proporsi produk ekspor berteknologi menengah dan tinggi. Kehadiran foreign direct investment (FDI) yang mempunyai potensi sebagai basis untuk alih teknologi belum dapat dimanfaatkan.

f. Kualitas SDM relatif rendah. Dari hampir 4,2 juta orang tenaga kerja industri dalam 22.894 perusahaan pada tahun 2006, hanya 2 persen berpendidikan sarjana, sekitar 0,1 persen berpendidikan master, dan 0,005 persen (hanya 225 orang) berpendidikan doktor. Sementara itu, intensitas pelatihan yang dilaksanakan oleh industri belum juga menggembirakan. Hasil survei tahun 1990-an menunjukkan hanya 18,9 persen perusahaan di Indonesia melaksanakannya. Di Malaysia, kegiatan yang sama dilakukan oleh hampir 84 persen perusahaan-perusahaannya. SDM dengan kualitas ini akan sulit diharapkan menghasilkan peningkatan produktivitas apalagi inovasi-inovasi yang bermutu untuk teknologi produksinya.

g. Iklim persaingan yang kurang sehat. Banyak sub-sektor industri yang beroperasi dalam kondisi mendekati "monopoli". Hal ini ditunjukkan dengan tingginya indeks konsentrasi 
untuk dua perusahaan (CR2). Pada tahun 2012, lebih dari 50 persen kelompok usaha industri memiliki angka diatas 0,50 dan banyak kelompok industri yang angka konsentrasi yang makin besar. Beberapa contoh adalah pada industri tepung terigu, rokok putih, dan kendaraan roda 2. Keadaan ini menyebabkan insentif untuk penurunan biaya produksi menjadi kecil.

h. Struktur industri masih lemah. Sebagai illustrasi, di industri kendaraan bermotor pada tahun 1997 jumlah produser komponen mencapai 155 perusahaan. Namun hampir semua produsen komponen ini merupakan pemasok lapis pertama. Hal ini menunjukkan lemahnya kedalaman struktur industri nasional otomotif. Sebagai perbandingan, pada tahun yang sama di Jepang ada 350 pemasok lapis pertama, 2.000 pemasok lapis kedua, dan 10.000 pemasok lapis ketiga. Artinya industri nasional sangat terintegrasi secara vertikal.

i. Peranan industri kecil dan menengah (termasuk RT) masih minim. Industri berskala menengah (20-99 orang tenaga kerja), berskala kecil (5-19 orang tenaga kerja), dan industri rumah tangga ( $1-4$ orang tenaga kerja) mempekerjakan dua pertiga tenaga kerja manufaktur di Indonesia. Namun demikian, segmen industri ini menyumbang hanya 5-6 persen dari total nilai tambah manufaktur. Industri kecil dan menengah terkonsentrasi di sub-sektor makanan dan kayu. Industri-industri pada segmen ini umumnya melayani konsumer akhir atau memproduksi komponen untuk "after sales market", dengan segmen kelas terendah. Sangat sedikit yang memproduksi bahan baku dan/atau barang intermediate serta memasoknya ke industri hilir. Dengan kondisi ini, industri kecil dan menengah di Indonesia belum berada dalam satu mata rantai pertambahan nilai dengan industri berskala besar.

j. Sebaran Industri yang terpusat di Pulau Jawa. Unit usaha industri merupakan pencipta kesejahteraan (wealth) terpenting melalui nilai tambah produk-produk yang dihasilkan dan sekaligus mendistribusikannya ke khalayak melalui pekerjanya. Oleh karena itu distribusi dari segmen industri ini juga akan mencerminkan distribusi kesejahteraan yang terbentuk. Menurut data tahun 2012, dari 21,146 usaha industri berskala menengah dan besar, 17.118 atau 80 persen di antaranya berada di Pulau Jawa.

1. Langkah-langkah dalam Undang-Undang Nomor 3 Tahun 2014 tentang Perindustrian dalam Mengatasi Deindustrialisasi

Langkah - langkah dalam Undang-Undang Nomor 3 Tahun 2014 tentang Perindustrian dalam mengatasi semua masalah yang menyebabkan deindustrialisasi belum lengkap. Artinya, tidak semua masalah yang menjadi penyebab deindustrialisasi akan ditemukan solusinya dalam undang-undang tersebut. Langkah untuk mengatasi deindustrialisasi yang sudah ada dalam Undang-Undang Nomor 3 Tahun 2014, antara lain sebagai berikut.

a. Peningkatan sumber daya manusia bidang industri

Pasal-pasal yang berkaitan dengan peningkatan sumber daya manusia di bidang industri, antara lain sebagai berikut.

1) Pasal 15

Pembangunan sumber daya Industri meliputi:

a) pembangunan sumber daya manusia;

b) pemanfaatan sumber daya alam;

c) pengembangan dan pemanfaatan Teknologi Industri;

d) pengembangan dan pemanfaatan kreativitas dan inovasi; dan

e) penyediaan sumber pembiayaan.

2) Pasal 16 tentang sumber daya manusia

a) Pembangunan sumber daya manusia Industri dilakukan untuk menghasilkan sumber daya manusia yang kompeten guna meningkatkan peran sumber daya manusia Indonesia di bidang Industri.

b) Pembangunan sumber daya manusia Industri sebagaimana dimaksud pada ayat (1) dilakukan oleh Pemerintah, Pemerintah Daerah, pelaku Industri, dan masyarakat.

c) Pembangunan sumber daya manusia Industri sebagaimana dimaksud pada ayat (1) 
memperhatikan penyebaran dan pemerataan ketersediaan sumber daya manusia Industri yang kompeten untuk setiap wilayah provinsi dan kabupaten/kota.

d) Sumber daya manusia Industri sebagaimana dimaksud pada ayat (1) meliputi:

i. wirausaha Industri;

ii. tenaga kerja Industri;

iii. pembina Industri; dan

iv. konsultan Industri.

b. Peningkatan penguasaan teknologi industry

Pasal-pasal yang berkaitan dengan peningkatan penguasaan teknologi industri, antara lain sebagai berikut.

1) Pasal 36 tentang pengembangan dan pemanfaatan teknologi industri

a) Pemerintah dan Pemerintah Daerah bertanggung jawab dalam pengembangan, peningkatan penguasaan, dan pengoptimalan pemanfaatan Teknologi Industri.

b) Pengembangan, peningkatan penguasaan, dan pengoptimalan pemanfaatan Teknologi Industri dilakukan untuk meningkatkan efisiensi, produktivitas, nilai tambah, daya saing, dan kemandirian bidang Industri.

c) Pengembangan, peningkatan penguasaan, dan pengoptimalan pemanfaatan Teknologi Industri dilaksanakan oleh Menteri setelah berkoordinasi dengan menteri terkait dan mempertimbangkan masukan dari pemangku kepentingan terkait.

2) Pasal 43 tentang pengembangan dan pemanfaatan inovasi dan kreativitas

a) Pemerintah dan Pemerintah Daerah memfasilitasi pengembangan dan pemanfaatan kreativitas dan inovasi masyarakat dalam pembangunan Industri.

b) Pengembangan dan pemanfaatan kreativitas dan inovasi masyarakat sebagaimana dimaksud pada ayat (1) dilakukan dengan memberdayakan budaya Industri dan/ atau kearifan lokal yang tumbuh di masyarakat.

c) Dalam rangka pengembangan dan pemanfaatan kreativitas dan inovasi masyarakat sebagaimana dimaksud pada ayat (2), Pemerintah dan Pemerintah Daerah melakukan:

i. penyediaan ruang dan wilayah untuk masyarakat dalam berkreativitas dan berinovasi;

ii. pengembangan sentra Industri kreatif;

iii. pelatihan teknologi dan desain;

iv. konsultasi, bimbingan, advokasi, dan fasilitasi perlindungan Hak Kekayaan Intelektual khususnya bagi Industri kecil; dan

v. fasilitasi promosi dan pemasaran produk Industri kreatif di dalam dan luar negeri.

c. Pembuatan kawasan industri sehingga tidak hanya terpusat di Jawa

Pasal-pasal yang yang berkaitan dengan pembuatan kawasan industri antara lain sebagai berikut.

1) Pasal 14 tentang Perwilayahan Industri

a) Pemerintah dan/atau Pemerintah Daerah melakukan percepatan penyebaran dan pemerataan pembangunan Industri ke seluruh wilayah Negara Kesatuan Republik Indonesia melalui perwilayahan Industri.

b) Perwilayahan Industri sebagaimana dimaksud pada ayat (1) dilakukan dengan paling sedikit memperhatikan:

i. rencana tata ruang wilayah;

ii. pendayagunaan potensi sumber daya wilayah secara nasional;

iii. peningkatan daya saing Industri berlandaskan keunggulan sumber daya yang dimiliki daerah; dan

iv. peningkatan nilai tambah sepanjang rantai nilai.

c) Perwilayahan Industri sebagaimana dimaksud pada ayat (2) dilaksanakan melalui: 
i. $\quad$ pengembangan wilayah pusat pertumbuhan Industri;

ii. pengembangan kawasan peruntukan Industri;

iii. pembangunan Kawasan Industri; dan

iv. pengembangan sentra Industri kecil dan Industri menengah.

d) Ketentuan lebih lanjut mengenai perwilayahan Industri sebagaimana dimaksud pada ayat (2) dan ayat (3) diatur dengan Peraturan Pemerintah.

2) Pasal 49 tentang pembangunan sarana dan prasarana industry

Pembangunan sarana dan prasarana Industri meliputi:

a) Standardisasi Industri;

b) infrastruktur Industri; dan

c) Sistem Informasi Industri Nasional.

d) Peningkatan kandungan lokal, perlindungan industri, dan penerapan SNI

Pasal-pasal yang berkaitan dengan peningkatan kandungan lokal, perlindungan industri, dan penerapan SNI

1) Pasal 85 tentang peningkatan penggunaan kandungan local

Untuk pemberdayaan Industri dalam negeri, Pemerintah meningkatkan penggunaan produk dalam negeri.

2) Pasal 88 tentang fasilitas kepada industri yang menggunakan kandungan lokal

Dalam rangka penggunaan produk dalam negeri sebagaimana dimaksud dalam Pasal 85, Pemerintah dapat memberikan fasilitas paling sedikit berupa:

a) preferensi harga dan kemudahan administrasi dalam pengadaan barang/jasa; dan

b) sertifikasi tingkat komponen dalam negeri.

3) Pasal 51 tentang penerapan SNI

a) Penerapan SNI oleh Perusahaan Industri bersifat sukarela.

b) Perusahaan Industri sebagaimana dimaksud pada ayat (1) yang telah menerapkan SNI dapat membubuhkan tanda SNI pada barang dan/atau Jasa Industri.

c) Terhadap barang dan/atau Jasa Industri yang telah dibubuhi tanda SNI sebagaimana dimaksud pada ayat (2), Perusahaan Industri harus tetap memenuhi persyaratan SNI.

4) Pasal 54 tentang sanksi bagi pelaku industriu yang tidak menerapkan SNI

Setiap barang dan/atau Jasa Industri yang tidak memenuhi SNI, spesifikasi teknis, dan/ atau pedoman tata cara yang diberlakukan secara wajib, pelaku usaha atau pemilik barang dan/atau Jasa Industri wajib menarik barang dan/atau menghentikan kegiatan Jasa Industri.

5) Pasal 96 tentang tindakan pengamanan industri

a) Dalam rangka meningkatkan ketahanan Industri dalam negeri, Pemerintah melakukan tindakan pengamanan Industri.

b) Tindakan pengamanan Industri dalam negeri sebagaimana dimaksud pada ayat (1) meliputi:

i. pengamanan akibat kebijakan, regulasi, dan/atau iklim usaha yang mengancam ketahanan dan mengakibatkan kerugian Industri dalam negeri; dan

ii. pengamanan akibat persaingan global yang menimbulkan ancaman terhadap ketahanan dan mengakibatkan kerugian Industri dalam negeri.

6) Pasal 100 tentang tindakan penyelamatan industri

a) Pemerintah dapat melakukan tindakan penyelamatan Industri atas pengaruh konjungtur perekonomian dunia yang mengakibatkan kerugian bagi Industri dalam negeri.

b) Tindakan penyelamatan Industri sebagaimana dimaksud pada ayat (1) paling sedikit dilakukan melalui:

i. pemberian stimulus fiskal; dan

ii. pemberian kredit program. 
c) Ketentuan lebih lanjut mengenai tindakan penyelamatan Industri diatur dalam Peraturan Pemerintah.

d. Peningkatan peran UKM

Pasal-pasal yang berkaitan dengan peningkatan peran UKM, antara lain sebagai berikut: Pasal 72 tentang industri kecil dan industri menengah yang menyatakan

1) Pemerintah dan/atau Pemerintah Daerah melakukan pembangunan dan pemberdayaan Industri kecil dan Industri menengah untuk mewujudkan Industri kecil dan Industri menengah yang:

a) berdaya saing;

b) berperan signifikan dalam penguatan struktur Industri nasional;

c) berperan dalam pengentasan kemiskinan melalui perluasan kesempatan kerja; dan

d) menghasilkan barang dan/atau Jasa Industri untuk diekspor.

2) Untuk mewujudkan Industri kecil dan Industri menengah sebagaimana dimaksud pada ayat (1) dilakukan:

a) perumusan kebijakan;

b) penguatan kapasitas kelembagaan; dan

c) pemberian fasilitas.

d) Peningkatan kerja sama industri

Pasal-pasal yang mengatur tentang peningkatan kerja sama industri, antara lain sebagai berikut:

1) Pasal 91 tentang kerja sama industri

a) Dalam rangka pengembangan Industri, Pemerintah melakukan kerja sama internasional di bidang Industri.

b) Kerja sama internasional di bidang Industri ditujukan untuk:

i. pembukaan akses dan pengembangan pasar internasional;

ii. pembukaan akses pada sumber daya Industri;

iii. pemanfaatan jaringan rantai suplai global sebagai sumber peningkatan produktivitas Industri; dan

iv. peningkatan investasi.

c) Dalam melakukan kerja sama internasional di bidang Industri sebagaimana dimaksud pada ayat (1), Pemerintah dapat:

i. menyusun rencana strategis;

ii. menetapkan langkah penyelamatan Industri; dan/atau

iii. memberikan fasilitas.

d) Dalam hal kerja sama internasional di bidang Industri sebagaimana dimaksud pada ayat

(2) berdampak pada Industri, terlebih dahulu dilakukan melalui konsultasi, koordinasi, dan/atau persetujuan Menteri.

2) Pasal 92 tentang pemberian fasilitas kerja sama internasional

Pemberian fasilitas kerja sama internasional di bidang Industri sebagaimana dimaksud dalam Pasal 91 ayat (3) huruf c paling sedikit meliputi:

a) bimbingan, konsultasi, dan advokasi;

b) bantuan negosiasi;

\section{Kesimpulan}

Penyebab deindustrialisasi di Indonesia, antara lain sebagai berikut: KKN dan layanan umum yang buruk; Cost of money yang relatif tinggi; administrasi perpajakan yang belum optimal; kandungan impor sangat tinggi; lemahnya penguasaan dan penerapan teknologi; kualitas SDM relatif rendah; iklim persaingan yang kurang sehat; struktur industri masih lemah; peranan industri kecil dan menengah (termasuk RT) masih minim; dan sebaran Industri yang terpusat di Pulau Jawa.

Langkah-langkah dalam Undang-Undang Nomor 3 Tahun 2014 tentang Perindustrian dalam 
mengatasi semua masalah yang menyebabkan deindustrialisasi belum lengkap. Artinya, tidak semua masalah yang menjadi penyebab deindustrialisasi akan ditemukan solusinya dalam undang-undang tersebut.

\section{Daftar Pustaka}

Balitbang Kementerian Perindustrian, 2013, Permasalahan Industri pada Era Otonomi Daerah, Jakarta: Balitbang Kementerian Perindustrian

Berly Martawardaya, 2013, PR Presiden Terpilih, artikel di Majalah Indonesia edisi 3/2013, Jakarta: Tempo Publishing

Dimas Jarot Bayu, Kadin: Selama 10 Tahun Indonesia Alami Deindustrialisasi, diakses dari katadata. com/2017/01/kadin-selama-10-tahun-indonesia-alami-deindustrialisasi, pada tanggal 3 April 2017, pukul 17. 55 WIB

Pratiwi Kartika, 2009, Aglomerasi Industri, Artikel Jurnal CSIS edisi 37/3, Jakarta: CSIS

Susi Meinara, 2010, Faktor-faktor yang Memengaruhi Deindustrialisasi di Indonesia Tahun 2000-2009, Tesis, Bogor: Sekolah Pascasarjana Insititut Pertanian

Undang-Undang Nomor 3 Tahun 2014 tentang Perindustrian

World Bank, 2014, Total Factor Productivity, USA: World Bank 